Indonesian Journal of EFL and Linguistics

Vol. 6 No. 1, 2021

eISSN: 2503-4197, pISSN: 2527-5070

www. indonesian-efl-journal.org

doi: http://dx.doi.org/10.21462/ijefl.v6i1.396

\title{
Technology Integration of the In-Service EFL Teachers: A Study at a Teacher Profession Education Program
}

\author{
Fatimah Tuzahra \\ Universitas Sriwijaya \\ e-mail: fatiimahshb@gmail.com \\ Sofendi (Corresponding Author) \\ Universitas Sriwijaya \\ e-mail: Sofendi@yahoo.com \\ Machdalena Vianty \\ Universitas Sriwijaya \\ e-mail: Machdalena074@yahoo.com
}

\begin{abstract}
:
Utilizing technology in the classroom characterizes the $21^{\text {st }}$ century teachers. Therefore, teachers are demanded to be able to use technology in pedagogical practices in order to fulfill their students' needs facing rapidly digitalized life. This study was designed to investigate the perceptions of a group of in-service English as Foreign Language (EFL) teachers who studied at a Teacher Profession Education program at a state university, concerning the application of technology within challenges they faced during their study. This study used qualitative research with narrative approach as a strategy of inquiry. The data were obtained by using a semi-structure interview with the in-service teachers and documentation. The data were analyzed using thematic analysis. The results of the study showed that the participants generally perceived positively the technology integration taught by their university instructors during their study time at the Teacher Profession Education program although there was a negative response when they were firstly introduced with the technology. It might have been caused by their lack of technological
\end{abstract}

Indonesian Journal of EFL and Linguistics, 6(1), 2021 
Fatimah Tuzahra, et al

knowledge. The result also revealed that the participants found it challenging when it came to the use of novel technology as introduced and applied by their university instructors. In addition, their own integration of technology during their Teaching Practice was a challenge due to the students' low motivation to engage in the online learning activity which was the mode of learning. The findings of this study suggest that teachers need to advance their skills and knowledge to utilize technology in supporting their pedagogical practices.

Keywords: In-service EFL teachers, Teacher Profession Education (Pendidikan Profesi Guru) program, technology integration

\section{INTRODUCTION}

The advancement of technology leads to paradigm shifts in 21 st century learning as the result of changes in current students' needs facing rapidly growing and digitalized life. Therefore, to meet the demands, the students nowadays should be equipped with a set of proficiencies which allow them to think, work to solve problems, make innovation, communicate and collaborate as well as contribute throughout their lives (Kay \& Grenhill, 2011), and the set of competencies thought to be crucial for students' working life refers to as 21 st century skills (Griffin et al., 2012). The 21 st century learning skills encompass four main competencies referring to the skills of the 4Cs including communication, collaboration, critical thinking, and creativity, and develop these skills. Yet, the engagement of technology in pedagogical practices should be considered. This is in accordance with Gelder's remark (2001) pointing out that today's learning approaches are more studentscentered and more stressed on varied learning needs of students, and by engaging the effective use of technology and the application of critical thinking skill, students can be prepared for the 21 st century work-force.

The actualization of integrating technology is indeed emphasized in the 21 st-century learning environment since it is crucial to get teachers to be engaged in technology and 21st-century learning and teaching strategies as expected of the 21st-century teachers in controlling the instructional process of the digital natives (Latchem \& Hanna, 2001). In addition, the effects of technology integration in teaching and learning activities have been extensively studied in various fields.- Glasset and Schrum (2009) claim that the benefit of successful technology integration in the classroom supports students in improving their attitudes in teaching and learning, their level of achievement and helping students to deepen their understanding toward curriculum content. In the field of computer-based learning, technological environment in the classroom can change students' attitudes and enhance their confidence (Lee, 2000). In the field of language learning, Chong (2001) reported 
that technology engagement in the classroom could be used to offering authentic materials for students and bridging teacher-students' communication. In the context of English Language Teaching (ELT), Park and Son (2009) investigated the factors affecting Korean EFL teachers' use of computers in their classroom. They concluded that computer technology was a powerful teaching aid helping students enhance their learning competencies in a real context and offering them varied language inputs as well.

To conclude, technology integration positively brings impact to students in teaching and learning process. Therefore, this is verily suggested in the $21^{\text {st }}$ century learning as it demands technology to be involved in learning environment as affirmed by Hoyles and Lagrance (2012) that today's learning is strongly influenced by the advancement of technology, so that the use of technology should be involved in pedagogical practices for effective learning, and in relation to this, Indonesian government has taken a step in keeping up with that by focusing on the professional development of teachers as the important agent in students' learning. One of the Indonesian government efforts is by having the PPG program (Program Pendidikan Profesi Guru--Teacher Professional Education Program).

The Regulation of Ministry of Education and Culture of Indonesia Number 87 of 2003 states that the ultimate goals of Teacher Profession Education Program are as follows:

a. to create prospective teachers to have competency in designing, implementing, and assessing the lesson;

b. to follow up assessment result while teaching and training the student; and

c. to be able conducting research and developing professionalism sustainably.

Teacher Profession Education Program is designed for both prospective teachers (pre-service) and teachers (in-service). Pre-service teacher education is the education and training provided to student teachers before they have undertaken any teaching. In contrast, in-service teacher education provides learning opportunities for practicing teachers. Pre-service teachers refer to undergraduate alumni from educational and non-educational fields who have capabilities and interests to be teachers, while in-service teachers refer to civil-servant and non-civil servant teachers who have teaching experiences in educational units. In the Teacher Profession Education Program, pre-service and in-service teachers are trained professionally in order for them to master teachers' competencies based on the national education standards. The study period of the Teacher Profession Education Program is two semesters or one year.

One of the criteria of professional teachers is that a professional teacher has to be able to use the ICT to communicate and develop self-potency in line with the $21^{\text {st }}$ century learning demand, and through the Teacher Profession Education Program, teachers can achieve those standard because the curriculum of Teacher Profession 
Education Program is created based on the TPACK (Technological Pedagogical Content Knowledge) framework which is considered as a basis aspect of teacher education. The curriculum of Teacher Profession Education Program refers to an activity-based curriculum where its application can be found during the workshop in developing teaching materials and this is reflected in the TPACK concept (Buku Pedoman Penyelenggaraan PPG, 2017). TPACK is one of the frameworks incorporating technological knowledge with both pedagogical and content knowledge in a contextual learning (Koehler et al., 2013). The framework of TPACK is emphasized in the Teacher Profession Education Program with respect to the support of the development of their students' $21^{\text {st }}$ century skills. It is in line with the Voogt et al. (2012) claiming that the teachers must be able to use not only different pedagogical approaches but also technological skill.

Investigation about technology integration has been widely investigated by scholars, for example, the studies of Lemke and Coughlin (1998), Waxman et al. (2003), and Gimbert and Cristol (2004) summarized the benefits of technology integration in improving students' achievement. Previous studies conducted by Hwang et al. (2016), Blachowicz et al. (2009), Case \& Truscoot (1999), and (Hoven, 1999) showed that technology integration helped the students to enhance their four English language skills. In relation to teacher profession education, the study conducted by Apriliaswati (2019) focused on the in- service English teachers' disposition toward developing pedagogical competence by technology literacy at Teacher Education Program at Tanjungpura University showed that the technology integration helped the participants enhance their technological skill. Another study about the application of technology integration at Teacher Profession program was carried out by Quddus (2019) reporting that the application of TPACK through online learning successfully increased the teachers' competence. Similarly, the study by Ahmed et al. (2019) indicated that technology integration assisted the teachers to improve their professional development. However, the study of Utami (2018) investigated about the perception of English teachers at the Teacher Profession Education Program in Universitas Pendidikan Ganesha reported that the participants found the online learning implementation difficult because of their lack of ICT skills, the incompleteness of the uploaded modules, instructors' unfamiliarity with learning software and the excessive assignments to be done in limited time.

Taking into consideration the different findings of the previous studies concerning technology integration within the Teacher Profession Education Program, this study aimed to investigate the integration of technology within the Teacher Profession Education Program of Sriwijaya University by involving the in-service EFL teachers as the participants. As it is known, the Covid-19 pandemic was still around in 2020 requiring the teaching and learning activities in Indonesia were conducted online. Likewise, the implementation of the Teacher Profession Education Program in 2020 in Indonesia was performed with the help of online learning platform. Therefore, it is worth noting that this study is expected to give a significant valuable contribution 
to the existing literature concerning in-service teachers' professional development, especially in the application the technology integration within the classroom. In particular, this study aimed to answer the following research questions:

1. What were the perceptions of the in-service EFL teachers about the technology integration in their learning activities at Teacher Profession Education Program of Sriwijaya University?

2. What challenges did the in-service EFL teachers have in using and integrating technology in their study at Teacher Profession Education Program of Sriwijaya University?

\section{LITERATURE REVIEW}

\subsection{Technology Integration}

The term technology is defined in a variety of definitions. In narrow description, technology is mostly linked with computer equipment, software and other electronic devices (U.S department of education, 2010; Woolf, 2010), whilst Kumar et.al (1999) illustrate the concept of technology containing two main components: first, as physical component comprising items for instance product, tooling, equipment, blueprints, techniques and processes, and the second, technology refers to the component of informational embracing know-how in management, marketing, production, quality control, reliability, skilled labor and functional areas. Burgelman et al. (1996) define technology as theoretical and practical of knowledge, skills and artifacts utilized to improve products and services as well as their production and delivery systems. When talking about technology, the notion of technology integration cannot be separated as it is interrelated process, and the notion of technology integration is widely discussed and defined by many scholars in related study field. In educational scope, Davies (2011, p.3) states that technology integration is the actual application of educational technology in accomplishing intended learning outcome, and educational technology is defined as "any tool, piece of equipment, or device-electronic or mechanical-that can be used to support instructional technologies for teachers and learning technologies for students to accomplish specified leaning goals." (p.31), and this is in line with what Shelly et al. (2008, p. 327) outline the definition of technology integration as the engagement of technology parts to improve learning outcomes for instance hardware and software along with subject-related area of curriculum. In a similar vein, Reigeluth and Joseph (2002, p.9) pointed out that technology integration is the way on how the technology is used in order to support the teaching practice done in schools. Since this study concerned about the technology, this study was framed with TAM (Technology Acceptance Model) theory.

Indonesian Journal of EFL and Linguistics, 6(1), 2021 
Fatimah Tuzahra, et al

\subsection{Technology Acceptance Model (TAM)}

TAM (Technology Acceptance Model) was firstly proposed by Davis (1989). The model was developed based on the Theory of Reasoned Action (TRA) introduced by Martin Fishbein and Icek Ajzen in 1975. According to Hu et al. (1999) TAM is specifically intended to describe users' acceptance of computer technology. The term of technology acceptance is portrayed by Dillon and Morris (1998) as "the demonstrable willingness within a user group to employ information technology (IT) for the tasks it was designed to support" (p. 5). Davis (1989) proposed this model based on two main conceptual ideas: Perceived Usefulness (PU) and Perceived Ease of Use (PEU). Perceived of Usefulness is illustrated as "the degree to which person believes that using particular system would enhance his/ her job performance." (Davis, 1989, p.320) while Perceived Ease of Use is depicted as "the degree of to which person believes that using particular system would be free of effort." (Davis, 1989, p.320)

The initial theory of TAM introduced by Davis (1989) was Behavioral Intention to Use (BIU), Attitude Toward Using (TIU) and Actual System of Use (ASU) besides the Perceived Usefulness (PU) and Perceived Ease of Use (PEU) and took the Actual System Use (ASU) as the main principle of this theory. Davis illustrated Actual System Use (ASU) as an observable use of certain system (i.e. technology) by individual. While Behavioral Intention to Use (BIU) is portrayed as the extent of individual designed their plan to do or not to do some particular future behavior (Davis, 1989). The Attitude Toward Using (ATU), on the other hand, is described as individual's perception whether it is positive or negative while performing the target behavior (Ajzen \& Fishbein, 2000). In this model, ATU is equally influenced by PU and PEU since both of them are affected by the external factors.

The theory of TAM then was further expanded by Vanketesh and Davis (1996) in order to deepen the factors of Perceived Ease of Use (PEU) and Perceived Usefulness (PU) (Vanketesh \& Davis, 2000). According to Vanketesh and Davis (1996), computer self- efficacy owned by users has significant role influencing Perceived Ease of Use (PEU) before and after they are exposed to technological system. While Perceived Usefulness (PU) was influenced by the social influence processes covering subjective norm, voluntariness, and image, and cognitive instrumental processes including job relevance, output quality, result demonstrability and perceived ease of use (Venkatesh \& Davis, 2000, p. 187). Both Perceived Usefulness (PU) and Perceived Ease of Use (PEU) are thought to distinguish particular aspects influencing individual perception toward the use of technology and it is confirmed by $\mathrm{Hu}$ et al. (1999) that there are many aspects determining individual behavior toward initial acceptance of technology but the basic aspects like perceived ease of use and perceived usefulness have a significant role for the next acceptance. 


\section{RESEARCH METHODOLOGY}

This section presents the methodology of research that was applied in this study. It consists of the discussion of the research design, research instrument, data collection procedure and data analysis. Since this study purposes to explore the experiences of the in-service EFL teachers toward the technology integration on their study at Teacher Profession Education Program, therefore, this study applied qualitative research approach, and for the strategy of inquiry, this study used narrative research. The narrative approach in this study aimed to see the outcome of interpretation instead of explanation in order to obtain the real data. The study was conducted at Teacher Profession Education Program in Sriwijaya University. The participants of this study were in-service EFL teachers, who attended the Teacher Professional Education Program from August to November, 2020. There were 56 in-service EFL teachers attending the Teacher Professional Education program. Before determining the respondents to be interviewed in-depth, a preliminary study was conducted to all 56 respondents by distributing open-ended questionnaires using a Google Form. There were three pre-set criteria to determine who would be the selected respondents. Arikunto (1989) defines that research respondents are selected by providing subject boundaries. For this reason, there were three pre-set criteria for choosing the respondents. First, the respondents were able to give clear terminology of technology integration in supporting learning activities outlined, following what Protheroe (2005) states that technology integration in motivating pedagogical practice means using technology to offer new insight in supporting innovative instructional model covering opportunities in collaborating and constructing knowledge for students. Second, the respondents were able to tell the application of technology integration both as students and teachers within its benefits. Third, the respondents were able to describe the challenges as well as its solution on the application of technology integration following what Labov (1997) states that narrative is a report of sequence of events that have entered into biography of the speaker by a sequence of clauses that correspond to the order of the original events. Of the 56 participants, only 19 of them sent back the response of the questionnaire. Based on the analysis of the response, there were only three respondents meeting the pre-set criteria.

The in-depth interview was conducted to the three selected respondents. It was carried out through the Zoom meeting. The interview was semi-structured, and the questions for the interview were developed based on TAM (Technology Acceptance Model) theory. The process of interviewing for each respondent took one hour and was conducted in Bahasa Indonesia in order to avoid misinterpretation regarding the questions being asked. The interviews were video recorded and transcribed. The 28 pages of the first interview from the three interviewed respondents were translated into English and categorized in the form of interview matrix. The process of transcription of each interview used clean transcript (Elliot, 2005) in which eliminated the pauses, intonation, false starts, and utterances that were commonly 
used in daily conversation. Consequently, the focus was given to the content of what the respondents told and made it easier to be understood. The transcription of the interview was then given back to the three respondents in order to re-check the responses that they had shared. Once it was completed, the next step was coding the data using in vivo. The process was illustrated by firstly conducting the in-vivo coding emphasizing the actual spoken words of participants.

Once in-vivo coding was formed, it then was reduced to categories and themes. The structure of data analysis applied the constant-comparative method involving reading and re-reading the transcripts. This process covered the actual coding of raw data and data categorization (Merriam, 1998, p. 161). The further step taken in analyzing the data was interpreting. The process of interpreting the data covered extensive meaning of the story illustrated in narrative covering the processes, theories, and specific features of data. The data were described in the form of pure narrative text followed by the discussion from both the writer's and experts' perspective. In relation to the trustworthiness, the writer used member checking to ensure the credibility of the information. Lincoln and Guba (1985) claim that the member checking is one of the most important establishments used in order to strengthen the credibility of a study. In this study, the respondents were allowed to read the transcripts of the dialogues that have been asked to them previously and they were also showed the re-telling stories (the combination of narrative and interview transcription). In addition, the data were supported by the documents derived from the participants in the form of lesson plans and social media posting.

\section{FINDINGS}

\subsection{In-service EFL Teachers' Perspectives on Technology Integration}

To answer the research question about in-service EFL teachers' perspective about technology integration during their study in Teacher Profession Education (PPG) Program, it started with some questions related to on how they perceived about the technology integration. In the beginning of the interview session, they were asked about their perspective regarding the application of the technology integration during their study. The data on in-service EFL teachers' perceptions toward technology integration during their study indicated that in-service EFL teachers perceived the technology integration as a positive contribution to their study since it offered new things to learn, hands-on real life learning experience, and opportunities to be more professional teachers. In addition, it can be assumed that the role of support obtained by the in-service EFL teachers influenced the application of technology integration in their study. The existence of support during their study made the in-service EFL teachers feel motivated and confident to use and apply technology in their study. The results of this study are further discussed through the categories explained below. 


\section{Demand of Using Technology}

The interview session with the three respondents concerning their perspectives about technology integration in their study, showed that all them claimed that the technology integration in their study positively enhanced their knowledge as they were supported to learn and share information from varied technological sources. However, there was a point showing that some negative emotions uttered by the respondents on the application of technology integration in their study. They reported that there was a controversial among the participants of in-service EFL teachers when the technology was infused in their study that some of them did not understand well about the technology. Meanwhile, the teaching and learning process was conducted online due to the Covid19 pandemic. In other words, the in- service EFL teachers seemed to lack technological knowledge.

Therefore, they had to learn the technology in order to keep up with the learning process as described by one of the respondents:

"Actually, there was a polemic in the first application of technology integration; there were pro and contra sides. For those who are in the pro side were people who have understood about technology, however, for those who were in the contra side were people who have not understood about technology. But now, we have to use the technology in our learning amidst pandemic. Like or dislike, everyone should learn about technology. For those who have understood, they can learn better but for those who have not understood, they have to learn to use it."

It is implied that the use of technology in teaching and learning process at the Teacher Profession Education (PPG) Program was demanded since it was conducted online. Therefore, the participants of the program were urged to understand and learn how to engage technology in their study although some of them lacked technological knowledge. However, in spite of the negative emotion showed at the first application of technology integration in their study, the in-service EFL considered that technology was helpful in their study as mentioned by the second respondent $(\mathrm{P} 2)$ :

"I think, technology was helpful for my study at PPG because at that time, I still lacked of technological knowledge. Frankly saying, at the first time of using Google Meet application, I was confused how to operate it, but gradually, I understood how to use that since when I have never used it before when I taught in my school."

That is to say the in-service EFL teachers thought that the technology integration made their learning process at the Teacher Profession Education (PPG) Program much easy as it enabled them to improve their performance during their study.

Positive Effects of Technology Integration

Indonesian Journal of EFL and Linguistics, 6(1), 2021 
Fatimah Tuzahra, et al

It is stated previously that in-service EFL teachers considered that the technology was beneficial for their study, and the table below illustrates the positive effects of technology integration perceived by the respondents based on the interview data.

Table 1. Positive Effects of Technology Integration

\begin{tabular}{|c|c|c|c|c|}
\hline No & $\begin{array}{l}\text { Positive Effects of } \\
\text { Technology } \\
\text { Integration }\end{array}$ & P1 & $\mathrm{P} 2$ & P3 \\
\hline 1. & $\begin{array}{l}\text { Knowing more } \\
\text { about kinds of } \\
\text { technology }\end{array}$ & $\begin{array}{l}\text { "What I got during my study } \\
\text { at PPG was I know about } \\
\text { varied web based application } \\
\text { that I did not know before." }\end{array}$ & - & $\begin{array}{l}\text { "I used to teach } \\
\text { monotonously by } \\
\text { using WhatsApp, } \\
\text { and now, I try to } \\
\text { be literate with } \\
\text { technology, so I } \\
\text { used Blog." }\end{array}$ \\
\hline 2. & $\begin{array}{l}\text { Being more } \\
\text { creative }\end{array}$ & $\begin{array}{l}\text { "For me, the benefit of } \\
\text { technology integration in the } \\
\text { classroom is allowing us to } \\
\text { become more creative } \\
\text { teachers." }\end{array}$ & - & $\begin{array}{l}\text { "I used Canva to } \\
\text { make learning } \\
\text { material more } \\
\text { interesting." }\end{array}$ \\
\hline 3. & $\begin{array}{l}\text { Learning new } \\
\text { things }\end{array}$ & $\begin{array}{l}\text { "While I was a student at } \\
\text { PPG, I learned a lot new } \\
\text { things such as making videos, } \\
\text { editing videos, and making } \\
\text { good evaluation." }\end{array}$ & $\begin{array}{l}\text { "I know more } \\
\text { applications like } \\
\text { Filmora and I } \\
\text { also understand } \\
\text { how to make E- } \\
\text { modules." }\end{array}$ & - \\
\hline 4. & $\begin{array}{l}\text { Making the } \\
\text { learning more } \\
\text { effective and } \\
\text { efficient }\end{array}$ & $\begin{array}{l}\text { "Applying technology in } \\
\text { teaching and learning process } \\
\text { amidst pandemic made the } \\
\text { process ran effectively and } \\
\text { efficiently." }\end{array}$ & $\begin{array}{l}\text { "By using } \\
\text { technology, the } \\
\text { learning process } \\
\text { is more effective, } \\
\text { more interesting } \\
\text { and more } \\
\text { efficient." }\end{array}$ & - \\
\hline 5. & $\begin{array}{l}\text { Being more } \\
\text { professional }\end{array}$ & $\begin{array}{l}\text { "While we were studying at } \\
P P G \text { so we could make our } \\
\text { own learning videos and it } \\
\text { was an interesting experience } \\
\text { in my opinion." }\end{array}$ & - & $\begin{array}{l}\text { "For me, } \\
\text { managing the } \\
\text { Blog makes me } \\
\text { feel that I can be } \\
\text { a professional } \\
\text { teacher." }\end{array}$ \\
\hline
\end{tabular}

Table1 shows that the technology integration benefited the in-service EFL teachers during their study at the Teacher Profession Program. The in-service EFL teachers considered that technology integration allowed them to upgrade their technological skills that it let them apply various kinds of both technology tools and technologybased applications in order to support them improve their performance in teaching and learning process. Besides, engagement of technology during their study impacted them in eliciting their creativity as they could be able to produce more interesting learning materials in more innovative ways and fulfill their students' 
need. Furthermore, it gave the in-service EFL teachers opportunity to upgrade themselves to be professional teachers by improving the ways they teach.

\section{The Role of Support in the Application of Technology Integration}

In the practice of technology integration, the support from both school and LPTK (Education Workforce Education Institutions) has an impact on successful integration of the technology in the respondents' study. The role of support in the application of technology integration is needed to encourage the in-service EFL teachers to use technology in their study and also to help them when they face some obstacles in its practice.

From the result of interview, the three in-service EFL teachers stated that they were supported when they involved technology in their study and it resulted positive outcomes toward the practice of technology integration at PPG Program. The first support mentioned by the in-service EFL teacher was the time flexibility provided by the school as stated by the first respondent:

"When talking about support, I got flexibility of teaching hours that my school gave. During PPG, my teaching hours were replaced by colleagues at my work so that I could take part the learning process at my home because I knew when I was going to PPG, I was more likely to study at home than at school to avoid technical problems because the learning activities at PPG took full day."

Besides the time flexibility, the respondent (P2) was also facilitated during her study from the school by lending the tablet PCs to her students while she was doing teaching practice because most of her students did not have gadgets to the learning process as she put in a nutshell:

"I was also facilitated by the school to lend tablets to students, who did not have gadgets to study when I was doing my teaching practice (PPL)"

The support also came from the LPTK and the lectures who taught them at the Teacher Profession Education (PPG) Program, The third respondent (P3) illustrated that the LPTK was responsive when they met problems in the application of technology integration as she said:

"While from the LPTK, it was very helpful when we had difficulties and the response was fast, for instance, when there was trouble using the LMS, the LPTK informed us to use another platform (Google Meet) therefore it made the learning process easier."

From the interview data, the in-service EFL teachers showed negative response in the first time of technology integration was applied in their study; however, as they got encouragement by the lecturers, they shifted their perspective toward the use of technology in their study as it was illustrated by the first respondent (P1): 
Fatimah Tuzahra, et al

"I think, I learned many things from what I used to do, Maybe, the best thing I did before PPG was using power point when I teach. But, now we were required to make our own learning videos with Animaker. At first, we complained to the lectures that we could not do that, but they convinced us that we could it. Therefore, we addicted to make learning videos because of support from the lecturers. Well, it turned out to be something good and it became a real satisfaction after making videos with Animaker."

The encouragement obtained by the in-service EFL teachers by the stake holders assisted them to enhance their technological skill and it was proven by the reviewed documentation of the respondents' lesson plans. The lesson plans showed, that the multiple technology tools and technology-based applications were applied. For instance, when the first participant taught the material about personal letter, she used a laptop and a cellphone to assist her. In addition, she applied Zoom meeting, Google Classroom, YouTube and PowerPoint as her media in teaching. In a similar vein, the third respondent applied Padlet (an online virtual bulletin board) to arrange learning material for teaching descriptive text. A further review was conducted on the social media postings displaying the respondents of this study successfully created videobased learning in their YouTube channel.

\subsection{Problems and Solutions in the Application of Technology Integration}

To answer this research question, the interview transcription and coding were used as the main resources. To begin with, the explanation was divided into two major factors, problems faced and challenges encountered by the in-service EFL teachers in using and integrating technology in their study at the Teacher Profession Education (PPG) Program. The result of this study indicated that the main problem faced by in-service EFL teachers was due to the technical problem, for example they were interfered by the signal when they tried to apply technology in their study. In addition, this study highlights that challenges in engaging technology in their study were caused by the illiteracy of in-service EFL teachers on technology-based application, lack of technological knowledge and students' reluctancy in participating the online class. The challenges and the solutions offered by the respondents are discussed as follows:

Technical Problems faced by in-Service EFL Teachers at Teacher Profession Education (PPG) Program

In regard to the problems in integrating technology by the in-service EFL teachers, the sole concern was brought into on how it worked with the technical problem in utilizing the technology. It can be assumed that those three respondents already agreed that the major technical problem which was very annoying and led to other problems was the networking bandwidth, signal. As follows, 
Technology Integration of the In-Service EFL Teachers

\section{Respondent 2}

"The main problem when applying technology during my study was the signal. Because at the time of PPG, I was given 3 days for the deadline in collecting the assignment and I haven't finished yet because there was no signal due to the blackout for 3 days so that the signal wasn't there at all. As a result, I couldn't have Zoom meeting at all so at that time I asked the students to meet face to face at school. If the lights went out in my area, it means there was also no signal."

\section{Respondent 3}

"Technical problems that occurred when applying technology might be signal, because during web meetings or even teaching during PPL, sometimes the sound was not clear, the picture also did not move due to the signal, especially when the lights went out. Because I used Wi-Fi at home, I had problems when the lights went out. Another technical problem I face was when the server in the LMS (Learning Management System) went down especially when it came to time to collect the tasks."

Due to the widely spread Coronavirus pandemic, the online learning has been inevitably crucial as an alternative way to conduct a teaching and learning process. As it is considered essential, the urgency of technology integration must be possessed, so is in the PPG program. Since the distance learning requires good WiFi signal and sufficient internet data quota for the students and teacher to get connected, it then became an inseparable factor to keep the teaching and learning process to take place. However, based on the interview result, the bad WiFi signal was the major technical problem faced by the participants. Addressing this problem, the three in-service EFL teachers as the respondents of this study already took several measures. Beside telling what they suffered due to poor network connection to the lecturers, such as asking permission to turn off the camera to make the connection less unstable. The participants also benefitted the use of media, as the respondent 1 described, “..... I did not mind it since there were recordings available in the LMS itself". Therefore, the students still could catch up the materials. In addition, Respondent 3 answered that she tried to use various type of networking providers to make sure that she could access the internet smoothly.

Challenges that the In-Service EFL Teachers Encountered in Integrating Technology during their study

As has been previously discussed about how the respondents used technology in their study amidst the pandemic, they declared that the biggest challenge was that they were demanded to upgrade their skills and knowledge toward the technology integration. The respondents realized they were quite illiterate to certain software applications or web-based applications, however in the long run they were able to operate it. As stated by respondent 2: 
Fatimah Tuzahra, et al

"I still lacked technological knowledge. Frankly saying, at the first time of Google Meet application, I was confused how to operate it, but gradually, I understood how to use that since when I never used it before when I taught in my school. I also never used Google Meet or Zoom, but I frequently used WhatsApp. When I was at PPG, I understood the use of the technology because the process of teaching and learning was conducted online"

Similarly, Respondent 3 mentioned;

"I think, I learned many things from what I used to do, Maybe, the best thing I did before PPG was using power point when I teach. But, now we were required to make our own learning videos with Animaker. At first, we complained to the lectures that we could not do that, but they convinced us that we could it"

From the above explanation, the challenges turn out into beneficial things to support the in-service professional education program students in their study especially for their teaching practice to school students. Despite all the advantages brought about from this challenge, more explanations are given on how this challenge encountered and how in- service EFL teachers coped with it.

\section{Lack of Video Editing Skill}

Once the writer asked about the particular skill or knowledge that the participants might still lack, the three respondents believed that it must have been the video editing skill.

Respondent 1:

"The biggest challenge engaging technology when I studied in PPG was editing video, therefore, in order to make a good and interesting video, the best way is using the back sound but I was commented by lecturers that my voice was too low and to overcome the problem was I minimized the sound"

Respondent 3:

"At the beginning I spent all day producing a learning video and it was also helped by my child, but gradually, I finally could spend 4-6 hours editing the video whereas my other colleagues only spent 1-2 hours"

The respondents were found lacking of this skill; they also claimed that there were other challenges in utilizing videos. To exemplify, the respondent 1 mentioned that some of the videos taken from several YouTube had watermark, moreover the enormous amount of byte of one video also sometimes could be a challenge for them to save or to distribute it to their students. Nevertheless, despite of all the challenges mentioned previously, they tried to cope with it by learning individually about how to make video using Google and YouTube, how to deal with delayed speech sound, 
too loud or too low back sound by using wonder share, video compression and so forth.

\section{Students' Reluctancy in Joining Online Learning}

Many students were found lacking of interest in enrolling online learning. This issue was predicted to be brought about by two major circumstances; demanding process of online learning and uninteresting materials. The demanding situation found was caused by the network constrain and complicated evaluation process. The following are the respondents' responses on the issue,

\section{Respondent 3}

"The challenge in engaging technology into learning that occurred during PPG was to invite the students to study online during PPL. There were many constrained by mobile data, network constraints and many others. Another challenge was to convince students that online learning is the same as face-to face learning as usual, it was difficult so it required struggle to do it especially when it came to evaluation; the process took a lot of time because of the slow response of students in submitting their response."

Furthermore, Respondent 2 opines,

“...... Another challenge is choosing interesting material as it could attract students to take part in the learning process and as the solution, I took an initiative way to provide additional hours besides class hours because there are some students working during pandemic and sometimes they didn't take part in learning, and to invite them to join classes outside class hours, I gave them a reward."

\section{DISCUSSION}

This study illustrates descriptive information regarding the perspectives owned by the in-service EFL teachers toward technology integration in their study within challenges they faced. The results of the analysis of interview indicated in-service EFL teachers responded positively, although at the first time of application, they showed negative emotions. Such factor, like lack of technological knowledge may lead this undesirable attitude to come out. In addition, this study draws special attention to the insufficient technological knowledge possessed by the teachers and students causing them to be reluctant in participating online learning. This becomes the challenges in the application of technology integration.

As teachers' actions are based on what they perceived (Ertmer, 2010; Pajares, 1992; Sadaf \& Johnson, 2017), the investigation on in-service EFL teachers' perceptions in the application of technology may result two different sides of perspectives as it is accordance with the theory of The Attitude Toward Using (ATU) as stated by Ajzen and Fishbein (2000) that in performing target behavior, there will be possibility that an individual shows either positive or negative 
perception. It was reported that there was a controversy among teachers when technology infused in their study that some of them did not understand well about it. Meanwhile, the teaching and learning process was performed with the help of online learning platform due to the Covid 19 pandemic. It can be assumed that the negative perception was resulted from the insufficient technological knowledge possessed by the in-service EFL teachers as the study of Vrasidas and Glass (2005) found that one of unsuccessful factors in the application of technology integration is caused by lack of teachers' content, technology and pedagogical knowledge. Similarly, the study of $\mathrm{Hu}$ and McGrath (2012) investigated the challenges in the application of ICT integration in colleges in China revealed that one of the problems in the technology integration like lack of teachers' knowledge about technology can thwart the technology implementation in pedagogical practice. Regardless of the negative attitude coming out to the surface, the in-service EFL teachers benefited technology integration in their learning process at the PPG Program as it enabled them to improve their performance during their study, and it relates to the Perceived of Usefulness (PU) of TAM (Technology Acceptance Model) theory as the extent of someone's belief toward the use of particular system in enhancing their performance (Davis, 1989, p.320), and this study, the in-service EFL teachers considered that technology integration was helpful and assisted them to work efficiently during their study.

Some studies also outline the positive benefits of technology integration on pedagogical practices felt by teachers for instance (Holinga, 1999; Guha, 2000; Sandholtz, 2001; Manzo, 2001; Sherry et al., 2001; Hong and Koh, 2002; Zorfass and Rivero, 2005, \& Almekhlafi, 2006a, 2006b). Furthermore, regarding the perspectives and experiences on technology integration training involving 17 social studies teachers, Zhao' study (2007) indicated that most teachers showed positive outcomes and they were enthusiastic to use technology during training and they found that technology integration in their training assisted them to work more productively. The result of this study also highlights that the in-service EFL teachers claimed that the technology integration led them to be creative teachers, and it was proven from social media posting owned by one of respondents that she successfully produced a creative video-based learning on her YouTube channel as shown in figure 1.

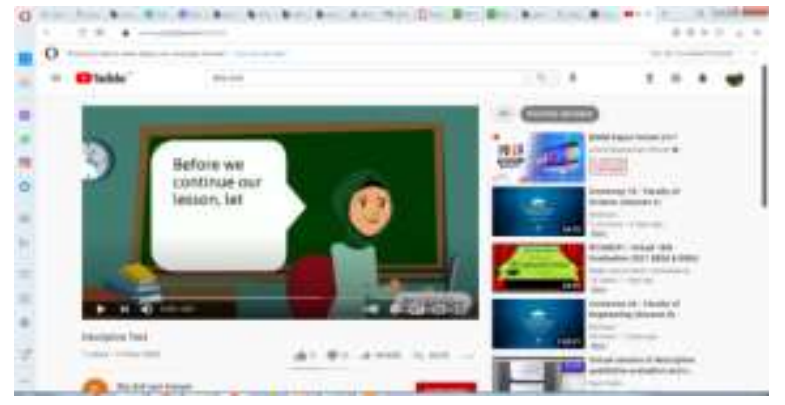

Figure: 1 Social Media posting of respondent 3 
The finding of this study also revealed that the technology integration in teaching and learning process helped in-service EFL teachers work efficiently, and this is in line with what Kotrlik and Redmann (2005) found in their study that though teachers doubt to integrate technology, they think that using technology makes their work more effective. The result of data analysis also outlined that in the process of incorporation technology, the role of support is undeniably important for EFL teachers in their study at the Teacher Profession Education (PPG) Program, and this in line with the study of Demps, Lincoln and Cifuentes (2011) that encouraging support for teachers enable them to get rewarding experiences and chances for teachers to focus on the quality of teaching process while using technology. In addition, some obstacles in technology integration are caused by inadequate sources, absence of both institutional and administrative encouragement, and lack of training and individual factors (Brinkerhoff, 2006). Although the previous studies shared similar findings with this present study, those discussed the technology integration in general ELT context while this study focused more on the Teacher Profession Education program context by exploring the experiences of the in-service EFL teachers toward the application of technology integration both as students and teachers in their study at the Teacher Profession Education program.

In relation to the problems met by the in-service EFL teachers in applying technology in their study, it was found that the internet network was their main concern, and it is accordance with the finding of Fauzan and Pimada's study (2018) that besides, ICT tool problem, the insufficient cellphone utilization applications age constraint, and limited internet access lead to the problems in the applications of technology integration. Moreover, in accordance to the statement of the participants, Nashruddin, Alam, and Tanasy (2020) discover that although the students have got the internet in their hands, they still face difficulty accessing the network due to the geographical area (remote area) they live in. As is mentioned, bad WiFi signals even loss signals resulted in students' inability to access the materials such as the sound was not clear, the server went down, and handing in the assignment causing the teaching and learning to become less effective.

Talking about challenges, the in- service EFL teachers considered that it was editing the video that became their biggest challenge when they were in the Teacher Profession Education (PPG) Program as they were asked to make video-based learning to make teaching and learning more interesting, as is stated by, Yousef, Chatti and Schroeder (2014) who suggest that Video-Based Learning (VBL) has been a long standing tradition. Similarly, Greenberg and Zanetis (2012) believe that educators and teachers must be encouraged to use videos more interactively which were proven to give positive impacts in learning. Lastly, another challenge faced by the in-service EFL teachers was inviting students to join online class, and it was assumed that the students got disconnected in distance learning as there were some pauses caused by poor internet network and as the consequence, the students were reluctant to join the online class as is in accordance with Rovai et, al in Gilbert 
Fatimah Tuzahra, et al

(2015) who state that in online learning, the students feel a weaker sense of connectedness compared to attending face-to face classes. In addition, one of the participants stated that choosing material was a very difficult task since it related to students' investment in participating online learning. Consequently, choosing interesting material is indeed emphasized in teaching and learning process as Mwiria (1995) stated that both quality and quantity of teaching sources determine students' performance in classroom. It can be assumed that, interesting material makes students more engaged in learning activities, and the study of King (2015) and Piertarinen et al. (2014) reveal that engagement plays crucial aspect in students' academic achievement.

\section{CONCLUSION}

In conclusion, this study aimed to find out the integration of technology in the Teacher Profession Education Program of Sriwijaya University. The findings show that the in-service EFL teachers found it difficult to incorporate technology because there were several constraints such as poor quality of internet networks, lack of technological knowledge, and poor students' involvement in participating online learning. However, they positively perceived the technology integration in their study. Based on the obstacles faced by the in-service EFL teachers, the following are the suggestions.

First, the TPEP SU should prioritize the participants' literacy because they will be involved in technology integration during their study in the program. Understanding the literacy paradigm is not only reading and reading materials, but also digital. Literacy is not just reading and writing, but also thinking skills using printed, visual, digital and auditory sources of knowledge.

Second is the fulfilment of internet access in all areas. By providing Internet access, digital literacy will be easier. A place that does not have a library can also be replaced with an e-library. The third is the implementation of the concept of literacy in the program. They are basic literacy, library literacy, media literacy, technology literacy and visual literacy.

Fourth, foster a love for science, truth and facts. This of course must be realized in reading activities that are balanced with validation, both digital and manual reading.

Fifth, participants have to change their lifestyle, starting from an oral culture, into a reading culture. On average, people don't read because they are busy making a living, don't like reading, and there is no reading material. In fact, they do not know what quality reading material is like. This is where literacy education is needed for the wider community. There must be a reading culture created by families and community groups rather than just talking that is useless.

The attempts and effort to get teachers updated, literate, and advanced in digital literacy requires stakeholders' role and support. The stakeholders for instance, 
regional department of education and cultures, school principals, teachers' working group should both facilitate and motivate teachers to enhance their skills. If necessary, the teachers must be required to join series of seminars or to participate in some teacher competitions or to attain some levels focusing on updating their skills in technology integration in teaching and learning.

\section{REFERENCES}

Ahmed, G., Arshad, M., \& Tayyab, M. (2019). Study of effects of ICT on professional development of teachers at university level. European Online Journal of Natural and Social Sciences, 8(2), 162-170.

Ajzen, I., \& Fishbein, M. (2000). Attitudes and the attitude-behavior relation: Reasoned and automatic processes. In W. Stroebe \& M. Hewstone (Eds.), European review of social psychology (pp. 1-33). Wiley.

Apriliaswati, R (2019, November 21-22). Disposition of in-service English teachers towards developing pedagogical competence by technology literacy [Paper presentation]. UICELL, Jakarta, Indonesia.

Arikunto, S. (1989). Prosedur penelitian: Suatu pendekatan praktik. Bumi Aksara.

Blachowicz, C., Bates, A., Berne, J., Bridgman, T., Chaney, J., \& Perney, J. (2009). Technology and at-risk young readers and their classrooms. Reading Psychology, 30 (5): 387-411

Brinkerhoff, J. (2006). Effects of a long-duration, professional development academy on technology skills, computer self-efficacy, and technology integration beliefs and practices. Journal of Research on Technology. 39, 22-43.

Burgelman, R.A., Maidique, M.A., \& Wheelwright, S.C. (1996). Strategic management of technology and innovation (2nd ed.). McGraw Hill.

Case, C. \& Truscott, D. (1999). The lure of bells and whistles: Choosing the best software to support reading instruction. Reading and Writing Quarterly,15 (4), 361-369.

Chong, D. H. (2001).The practical considerations of the Internet in the EFL classroom. Journal of Multimedia-Assisted Language Learning, 3(2), 9-35.

Davies, R. (2011). Understanding technology literacy: A framework for evaluating educational technology integration. Tech Trends, 55(5), 45-52.

Davis, F. D. (1989). Perceived usefulness, perceived ease of use and user acceptance of information technology. Management Information System. Quarterly, 13 (3), 319-339

Demps, E., Lincoln, Y., \& Cifuentes, L. (2011). Conflicts over the utilities of teaching

using educational technologies: An interpretive critical inquiry. Advances in Developing Human Resources , 13(2), 135-170. 
Fatimah Tuzahra, et al

Dillon, A. \& Morris, M. (1998). From "can they" to "will they?": Extending usability evaluation to address acceptance. In E. D. Hoadley \& B. Izak (Eds.), Proceedings Association for Information Systems Conference. Baltimore, MD.

Elliot, J. (2005). Using narrative in social research. Sage.

Etmer, P., A., \& Leftwich, O. (2010).Teacher technology change: how knowledge, beliefs, and culture intersect. Journal of Research Technology in Education, 42, 255-284

Fauzan, U., Pimada, L. H. (2018). ICT-based teaching of English at madrasah aliyah in kalimantan. TARBIYA: Journal of Education in Muslim Society, 5(2), 193-211.

Fishbein, M. \& Ajzen, I. (1975). Belief, attitude, intention, and behavior: An introduction to theory and research. Addison-Wesley.

Gelder, T. V. (2001). How to improve critical thinking using educational technology. ASCILITE 2001 Conference Proceeding (pp.539-548).

Glassett, K., \& Schrum, L. (2009). Teacher beliefs and student achievement in technology-rich classroom environments. International Journal of Learning Technology, 5(2), 138-153.

Gimbert, B., \& Cristol, D. (2004). Teaching curriculum with technology: Enhancing children's technological competence during early childhood. Early Child Development and Care, 31(3), 207-216.

Greenberb, A., D., \& Zanetis, J. (2012). The impact of broadcast and streaming video in education. https:// www.cisco.com/web/strategy/docs/education/ciscovideowp.pdf

Griffin, P., McGaw, B., \& Care, E. (2012). The changing role of education and schools. In P. Griffin, B. McGaw, \& E. Care (Eds.), Assessment and Teaching of 21st Century Skills (pp. 1-16).

Guha, S. (2000). A Comparative analysis of present and preferred situations of elementary grade teachers in using computers for classroom instruction, ERIC Document Reproduction Service No. ED440089.

Hall, G. E., \& Hord, S. M. (2001). Implementing change: Patterns, principles and potholes. Allyn \& Bacon

Harris, J., Grandgenett, N., \& Hofer, M. (2010, March). Testing a TPACK based technology integration assessment rubric. In D. Gibson \& B. Dodge (Eds.), Proceedings of the Society for Information Technology \& Teacher Education International Conference 2010 (pp. 3833-3840).

Holinga, M. J. (1999). Project LINCOLN: improving and enhancing student learning. Learning and Leading with Technology, 26 (7), 54-80.

Hong, K., \& Koh, C. (2002). Computer anxiety and attitudes toward computers among rural secondary school teachers: A Malaysian perspective. Journal of Research on Technology in Education, 35 (1), 27-46.

Hoven, D. (1999). A model for listening and viewing comprehension in multimedia environments. Language Learning and Technology, 3 (1), 73-90. 
Hoyles, C., \& Lagrange J.B. (Eds.). (2010). Mathematics education and technology - Rethinking the terrain. Springer.

Hu, P. J., Chau, P. Y. K., Sheng, O. R. L. \& Tam, K. Y. (1999). Examining the technology acceptance model using physician acceptance of telemedicine technology. Journal of Management Information System, 16 (2), 91-112.

$\mathrm{Hu}$, Z., \& McGrath, I. (2012). Integrating ICT into college English: An implementation study of a national reform. Education Information Technology, 17 (92), 147-165

Hwang, W. Y., Shadiev, R., Hsu, J. L., Huang, Y. M., Hsu, G. L., \& Lin, Y. C. (2016). Effects of storytelling to facilitate EFL speaking using Web-based multimedia system. Computer Assisted Language Learning, 29(2), 215-241.

Jang, S. J. (2009). Exploration of secondary students' creativity by integrating webbased technology into an innovative science curriculum. Computer and Education, 52, 247-255

Kay, K. \& Greenhill, V. (2011). Twenty-first century students need 21st century skills. In G, Wan \& D.M, Gut, (Eds.), Bringing schools into the 21 st century (pp. 41-65). London \& New York: Springer

Kementerian Pendidikan dan Kebudayaan Republik Indonesia. (2013). Peraturan menteri pendidikan dan kebudayaan RI nomor 87 tahun 2013 tentang program pendidikan profesi guru pra-jabatan. Jakarta: Kementerian Pendidikan dan Kebudayaan.

King, R. B. (2015). Sense of relatedness boosts engagement, achievement, and wellbeing: A latent growth model study, Contemporary Educational Psychology, 42, 26-38

Koehler, M.J., \& Mishra, P. (2008). Introducing TPACK. In AACTE Committee on Innovation \& Technology (Eds.).Handbook of technological pedagogical content knowledge for educators. (pp. 3-29). Routledge

Koehler, M. J., Mishra, P., Ackaoglu, M., \& Rosenberg, J. M. (2013). The Technological pedagogical content knowledge framework for teachers and teacher educators. Commonwealth Educational Media Center for Asia.

Kotrlik, J., \& Redmann, D. (2005). Extent of technology integration in instruction by adult basic education teachers. Adult Education Quarterly, 55: 200-219,

Kumar, V., Kumar, U., \& Persaud, A. (1999).Building technological apability through importing technology: The case of Indonesian manufacturing industry. Journal of Technology. Transfer, 24, 81-96.

Labov, W. (1997). Some further steps in narrative analysis. Journal of Narrative and Life History, 7 (1-4), 395-415.

Latchem, C. \& D. Hanna. (2001). Leadership for $21^{\text {st }}$ century learning: Global perspective from educational innovators.: Kogan Page.

Lee, K. (2000). English teachers' barriers to the use of computer-assisted language learning. Internet TESL Journal, 6(12).

Lincoln, Y. S., Guba, E. G. (1985). Naturalistic inquiry. Sage. 
Lundeberg, M., Bergland, M., Klyczek, K. \& Hoffman, D. (2003).Using action research to develop pre-service teachers' confidence, knowledge and beliefs about technology. Journal of Interactive Online Learn, 1 (4).

Manzo, K. K. (2001). Academic record. Educational Weekly, 20(35), 22-35.

Merriam, S. B. (1998). Qualitative research and case study applications in education. Jossey-Bass Publishers.

Mwiria, K. (1995). Issues in educational research in africa. East African Educational Publishing Limited.

Nashruddin, N., Alam, F. A., \& Tanasy, N. (2020). Perceptions of teacher and stjudents on the use of e-mail as a medium in distance learning. BERUMPUN: International Journal of Social Politics and Humanities, 3(2): 182-194.

Neiss, M. L. (2005). Preparing teachers to teach science and mathematics with technology: Developing a technology pedagogical content knowledge. Teaching and Teacher Education, 21(5), 509-523.

Pajares, M. F. (1992). Teachers' beliefs and educational research: Cleaning up a messy construct. Review of Educational Research, 62(3), 307-332

Park, C. N., \& Son, J. B. (2009).Implementing computer-assisted language learning in the EFL classroom: Teachers' perceptions and perspectives. International Journal of Pedagogies and Learning, 5(2), 80-101.

Patton, M. Q. (2002). Qualitative research \& evaluation methods. Sage Publications

Piertarinen, J., Soini, T., \& Pyhalto, K. (2014). Students' emotional and cognitive engagement as the determinats of well-being and achievement in school. International Journal of Educational Research, 67: 40-51b

Preston, C., Cox, M. J., \& Cox, K. M. J. (2000). Teachers as Innovators: An evaluation of the motivation of teachers to use information and communications technologies. King's College London and Mirandanet

Protheroe, N. (2005). Technology and students achievement. NAESP. https://www.yumpu.com/en/document/read/31800303/technology-and-studentachievement-national-association-of-

Quddus, A. (2020). Implementasi technological pedagogical content knowledge (TPACK) dalam pendidikan profesi guru (PPG) PAI LPTK UIN Mataram. Journal Tatsqif, 17(2), 213-230.

Reigeluth, C., \& Joseph, R. (2002). Beyond technology integration: the case for technology transformation. Educational Technology, 42 (4), 9-16.

Rovai, A. P., Wighting, M. J., \& Liu, J. (2005). School climate: Sense of classroom and school communities in online and on-campus higher education courses. Quarterly Review of Distance. Education, 6(4), 361-374

Sadaf, A., \& Johnson, B. (2017). Teachers' belief about integrating digital literacy into classroom practice: An investigation based on the theory of planned behavior. Journal of Digital Learning in Teacher Education, 33(4), 129-137. 
Sandholtz, J. H. (2001). Learning to teach with technology: A Comparison of teacher development programs. Journal of Technology and Teacher Education, 9, (3), 349.

Shelly, G.B., Cashman, T.J., Gunter, G.A., and Gunter, R.E. (2008). Educators discovering computers: Integrating technology and digital media in the classroom. (5 ${ }^{\text {th }}$ ed.). Thomson

Sherry, L., Bilig, S., Jesse, D., \& Acosta, D. W. (2001). Assessing the impact of instructional technology on student achievement. T.H.E. Jornal, 28 (7), 40-43.

Utami, I. G. L. P. (2018). The online learning of teacher profession education program (PPG) for in-service English teachers: Challenges and accelerated learning factors. Indonesia Journal of Education, 7 (2), 145-153

U.S. Department of Education (2010).Transforming American education: Learning powered by technology.National Education Technology Plan 2010. Office of Educational Technology: Washington, D.C.

Venkatesh, V., Morris, M. G., Davis, F. D. \& Davis, G. B. (2003). User acceptance of information technology: Toward a unified view. MIS Quarterly, 27(3), 425478.

Voogt, J., Fisser, P., Pareja Roblin, N. N., Tondeur, J., \& van Braak, J. (2013). Technological Pedagogical Content Knowledge - A review of the literature. Journal of computer assisted learning, 29(2), 109-121

Waxman, H.C., Lin, M-F., \&Michko, G.M. (2003). A meta-analysis of the effectiveness of teaching and learning with technology on student outcomes. Learning Point Associates. Retrieved from http:/ /www.ncrel.org/tech/effects2/waxman.pdf

Woolf, B. P. (2010). A roadmap for education technology. National Science Foundation.

You, J. W., \& Kang, M. (2014). The role of academic emotions in the relationship between perceived academic control and self-regulated learning in online learning. Computer Education, 77, 125-133.

Yousef, A., Mohammed, F., Chatti, M., \& Schroeder, U. (2014). The state of videobased learning: A review and future perspectives. International Journal of Advanced Life Science, 6 (3), 122-135.

Zhao, Y. (2007). Social studies teachers' perspectives of technology integration. Journal of Technology and Teacher Education, 15 (3), 311-333.

Zhao, Y. (2003). What teachers should know about technology: Perspectives and practices. Information Age. 